\title{
Targeting uroporphyrinogen decarboxylase for head and neck cancer treatment
}

\author{
Emma Ito ${ }^{1,2^{*}}$, Shijun Yue ${ }^{2}$, Eduardo H Moriyama ${ }^{1}$, Angela B Hui ${ }^{2}$, Inki Kim², Wei Shi ${ }^{2}$, Nehad M Alajez ${ }^{2}$, \\ Nirmal Bhogal ${ }^{2}$, GuoHua Li ${ }^{3}$, Alessandro Datti ${ }^{4,5}$, Aaron D Schimmer ${ }^{1,2}$, Brian C Wilson ${ }^{1}$, Peter P Liư ${ }^{3}$, \\ Daniel Durocher ${ }^{4}$, Benjamin G Neel ${ }^{1,2}$, Brian O'Sullivan ${ }^{6,7}$, Bernard Cummings ${ }^{6,7}$, Rob Bristow ${ }^{1,2,6,7}$, Jeff Wrana ${ }^{4}$, \\ Fei-Fei Liu ${ }^{1,2,6,7}$
}

From São Paulo Advanced School of Comparative Oncology Águas de São Pedro, Brazil. 30 September - 6 October 2012

\section{Background}

Head and neck cancer (HNC) is the $8^{\text {th }}$ most common malignancy worldwide. Despite advances in therapeutic options over the last few decades, treatment toxicities and overall clinical outcomes have remained disappointing, underscoring a need to develop novel therapeutic approaches, particularly those that enhance tumor cell death, while minimizing damage to the surrounding normal tissues.

\section{Materials and methods}

An RNA interference (RNAi)-based high-throughput screen (HTS) was performed for the large-scale identification of novel genes that will selectively sensitize HNC cells to ionizing radiation. The Dharmacon Protein Kinase and Druggable Genome siRNA Libraries were screened using FaDu cells (human hypopharyngeal squamous cell cancer). Radiosensitizing targets were subjected to in vitro and in vivo characterizations.

\section{Results}

Sixty-seven target sequences with potential radiosensitizing effects were identified. Targets reducing the surviving fraction by $>50 \%$ at 2 Gy relative to their un-irradiated counterparts were selected for further evaluation. A key regulator of heme biosynthesis, uroporphyrinogen decarboxylase (UROD), was thereby identified as a novel tumor-selective radiosensitizing target, demonstrating both in vitro and in vivo efficacy. Radiosensitization appeared to be mediated via enhancement of tumor

\footnotetext{
* Correspondence: emma.ito@rmp.uhn.on.ca

'Department of Medical Biophysics, University of Toronto, Toronto, Canada

Full list of author information is available at the end of the article
}

oxidative stress from perturbation of iron homeostasis and increased free radical production. UROD was significantly over-expressed in HNC patient biopsies, wherein lower pre-radiation mRNA levels correlated with improved survival, suggesting UROD could potentially predict radiation response. UROD down-regulation also radiosensitized several different human cancer models, while sparing normal cells.

\section{Conclusions}

An RNAi-based radiosensitizer HTS has revealed UROD as a potent tumor-selective sensitizer for radiation, with potential relevance to many human malignancies.

\section{Financial support}

Canadian Institutes of Health Research (CIHR; grant 69023); Elia Chair in Head and Neck Cancer Research; philanthropic support from Wharton Family, J. Finley, and G. Tozer; Campbell Family Institute for Cancer Research; Ministry of Health and Long-Term Planning; CIHR Resource Maintenance grant (PRG-82679).

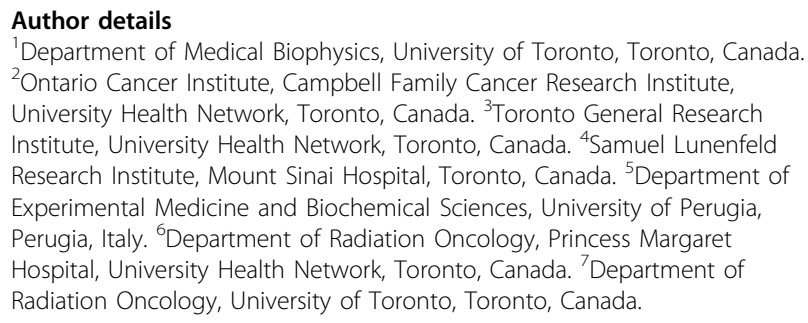

Published: 4 April 2013 
doi:10.1186/1753-6561-7-S2-P19

Cite this article as: Ito et al:: Targeting uroporphyrinogen decarboxylase

for head and neck cancer treatment. BMC Proceedings 2013 7(Suppl 2):

P19.

Submit your next manuscript to BioMed Central and take full advantage of:

- Convenient online submission

- Thorough peer review

- No space constraints or color figure charges

- Immediate publication on acceptance

- Inclusion in PubMed, CAS, Scopus and Google Scholar

- Research which is freely available for redistribution

Submit your manuscript at 